\title{
PEMANFAATAN KURVA BELAJAR LOG-LINEAR UNTUK PENGHEMATAN BIAYA PEKERJA
}

\author{
Vincent $^{1}$ dan Onnyxiforus Gondokusumo ${ }^{2}$ \\ ${ }^{\text {I}}$ Program Studi Sarjana Teknik Sipil, Universitas Tarumanagara, Jl. Letjen S. Parman No.1 Jakarta \\ Email: yohanesvincentpangestu@gmail.com \\ ${ }^{2}$ Program Studi Sarjana Teknik Sipil, Universitas Tarumanagara, Jl. Letjen S. Parman No.1 Jakarta \\ Email: onnyxiforusg@pps.untar.ac.id
}

\begin{abstract}
ABSTRAK
Pada proyek konstruksi banyak pekerjaan berulang yang dikerjakan dalam unit tertentu. Pekerjaan dinding merupakan salah satu contoh dari pekerjaan berulang ini. Pekerjaan ini sering ditemui pada bangunan tipikal dan perumahan. Proses berulang pada pekerjaan ini dapat menyebabkan peningkatan produktivitas pekerja sehingga waktu dan biaya yang dibutuhkan untuk menyelesaikan satu unit pekerjaan menjadi berkurang seiring dengan bertambahnya jumlah unit yang telah dikerjakan. Fenomena ini tentunya dapat dimanfaatkan untuk meningkatkan efisiensi dari pekerjaan tersebut. Namun masih banyak proyek yang tidak memperhitungan pengurangan durasi tersebut. Hal ini menjadi suatu hal yang sangat disayangkan mengingat bahwa jumlah pekerja dapat dikurangi ketika durasi pengerjaan berkurang. Oleh karena itu, penelitian ini menggunakan kurva belajar log-linear sebagai cara untuk memprediksi dan menghitung pengurangan durasi tersebut. Penelitian ini dilakukan dengan mengambil sampel data di dua proyek daerah Jabodetabek. Hasil dari penelitian ini menunjukkan bahwa kurva belajar log-linear baik digunakan untuk memprediksi durasi pekerjaan dinding dan juga metode pada penelitian ini yang digunakan untuk menghitung penghematan biaya pekerja semakin baik digunakan pada proyek dengan jumlah repetisi pekerjaan yang lebih banyak.

Kata kunci : pekerjaan dinding, prediksi durasi pekerjaan, kurva belajar log-linear, biaya pekerja, penghematan biaya.
\end{abstract}

\section{PENDAHULUAN}

\section{Latar Belakang}

Dewasa ini kebutuhan akan infrastruktur semakin meningkat. Peristiwa ini didasari oleh semakin bertambahnya populasi penduduk serta pola hidup masyarakat yang semakin modern. Proses ini menyebabkan bertambahnya berbagai tantangan dan tuntutan akan pembangunan.

Pelaksanaan pembangunan suatu konstruksi perlu dilaksanakan dengan perencanaan dan pengelolaan yang baik. Hal ini sejalan dengan semakin besarnya ukuran proyek dan semakin rumitnya ketergantungan antara satu bagian pekerjaan dengan pekerjaan yang lain dalam satu proyek untuk mencapai hasil yang diinginkan.

Tahap Perencanaan merupakan tahap yang penting dalam pembangunan. Tahapan ini sangat menentukan hasil suatu konstruksi, mengingat tahap ini menghasilkan desain dari suatu proyek yang akan dibangun. Perencanaan proyek konstruksi yang kurang efisien menyebabkan kerugian bagi kontraktor untuk memenangkan tender konstruksi.

Pada proyek konstruksi banyak pekerjaan yang dilakukan berulang dalam unit tertentu. Pekerjaan dinding merupakan salah satu contoh dari pekerjaan berulang ini. Pekerjaan ini sering ditemui pada bangunan tipikal dan perumahan. Proses berulang pada pekerjaan ini dapat menyebabkan peningkatan produktivitas pekerja sehingga waktu dan biaya yang dibutuhkan untuk menyelesaikan satu unit pekerjaan menjadi berkurang seiring dengan bertambahnya jumlah unit yang telah dikerjakan (Zhang et al., 2014). Fenomena ini tentunya dapat dimanfaatkan untuk meningkatkan efisiensi dari pekerjaan tersebut.

Namun masih banyak proyek yang tidak memperhitungan pengurangan durasi tersebut. Hal ini menjadi suatu hal yang sangat disayangkan mengingat bahwa jumlah pekerja dapat dikurangi ketika durasi pengerjaan berkurang. Oleh karena itu, penelitian ini menggunakan kurva belajar log-linear sebagai cara untuk memprediksi dan menghitung pengurangan durasi tersebut. 


\section{Rumusan Masalah}

Rumusan masalah dari penelitian ini adalah sebagai berikut:

1. Bagaimana peningkatan produktivitas suatu pekerjaan dengan kurva belajar log-linear?

2. Apakah penerapan kurva belajar log-linear menghasilkan prediksi durasi pekerjaan yang akurat?

3. Berapa besar penghematan biaya pekerja yang dapat dilakukan ketika kurva belajar log-linear diterapkan pada suatu pekerjaan?

\section{Maksud dan Tujuan}

Maksud dari penelitian ini adalah mencoba kurva belajar log-linear sebagai cara untuk memprediksi durasi pekerjaan dan melakukan penghematan biaya pekerja.

Tujuan dari penelitian ini adalah sebagai berikut:

1. Untuk mengetahui bagaimana peningkatan produktivitas suatu pekerjaan dengan kurva belajar log-linear.

2. Untuk mengetahui apakah penerapan kurva belajar log-linear menghasilkan prediksi durasi pekerjaan yang akurat.

3. Untuk mengetahui berapa besar penghematan biaya pekerja yang dapat dilakukan ketika kurva belajar loglinear diterapkan pada suatu pekerjaan.

\section{Batasan Penelitian}

Batasan penelitian ini adalah sebagai berikut pengambilan data dilakukan pada dua proyek perumahan di daerah Jabodetabek. Penelitian ini berfokus pada pekerjaan dinding (pemasangan batu bata, plesteran, acian, cat dasar dan cat finish) pada proyek perumahan sebagai objek penelitian pekerjaan berulang. Penghematan biaya pekerja pada penelitian ini terbatas pada upah yang dibayarkan kepada pekerja. Analisis prediksi durasi pekerjaan dinding menggunakan kurva belajar log-linear. Penelitian ini memakai bahasa pemograman Ruby untuk menyelesaikan algoritma pengurangan jumlah pekerja pada pekerjaan dinding.

\section{LANDASAN TEORI}

Peribahasa Inggris practice makes perfect adalah peribahasa yang nyata terjadi di semua budaya. Dari pengalaman, waktu dan usaha yang dibutuhkan untuk melakukan sebuah pekerjaan berkurang seiring dengan jumlah pengulangan dilakukan. Pengurangan ini disebabkan oleh fenomena yang disebut efek belajar yang disajikan secara matematis oleh kurva belajar (Srour et al., 2015).

Konsep kurva belajar berasal dari industri pesawat terbang dan pertama kali diusulkan oleh T. P. Wright pada tahun 1936 (Lee et al., 2015). Selanjutnya, menurut Argote dan Epple penerapan efek belajar menyebar ke berbagai sektor industri seperti industri otomotif, industri kimia, industri panel surya dan industri semikonduktor. Sejalan dengan hal tersebut, industri konstruksi tidak jauh berbeda dan juga diuntungkan ketika menerapkan konsep kurva belajar ini (Rosenbaum et al., 2012).

Proses pembelajaran pada industri konstruksi tidak berjalan secara instan dan berlangsung secara bertahap. Proses ini terbagi menjadi dua tahap, yakni: Tahap pembelajaran sistem operasi dan tahap memperoleh rutinitas (Thomas et al., 1986; Gottlieb dan Haugbolle, 2010). Pada tahap pembelajaran sistem operasi, pekerja memperoleh pengetahuan dasar akan pekerjaan yang dilakukannya. Berikutnya pada tahap memperoleh rutinitas, pekerja mulai terbiasa dengan pekerjaan tersebut, Adapun kedua tahapan ini dapat terjadi secara bersamaan yang mengakibatkan peningkatan kecepatan pekerja yang lebih besar.

\section{Produktivitas}

Produktivitas merupakan istilah dalam kegiatan produksi sebagai rasio antara output dan input atau rasio antara hasil produk dengan total sumber daya yang digunakan (Ervianto, 2007). Produktivitas dapat digunakan sebagai indikator keberhasilan suatu industri dalam menghasilkan barang atau jasa. Ukuran-ukuran produktivitas bisa bervariasi tergantung pada aspek-aspek output atau input yang digunakan. Adapun produktivitas yang dimaksud pada skipsi ini adalah perbandingan antara hasil volume pekerjaan terhadap durasi pekerjaan yang dibutuhkan. Sedangkan efisiensi pekerjaan bermakna sebagai peningkatan produktivitas melalui upaya pengurangan sumber daya yang digunakan (input) tanpa mempengaruhi hasil produk (output). 


\section{Kurva Belajar}

Teori kurva belajar didasari oleh fenomena peningkatan produktivitas melalui pekerjaan yang dilakukan berulang. Berbagai penelitian menyarankan efek dari kurva belajar dapat diterapkan pada industri konstruksi dikarenakan pekerjaan konstruksi pada umumnya dilakukan secara berulang (Thomas et al., 1986). Penelitian terdahulu mengindikasikan bahwa semakin identik pekerjaan berulang yang dilakukan oleh pekerja maka peningkatan produktivitas akan semakin besar (Lee et al., 2015). Dengan kata lain, Project Manager dapat memperoleh perencanaan yang lebih efisien melalui fenomena peningkatan produktivitas ini.

Di sisi lain, efek dari kurva belajar bermakna bahwa setiap rata-rata durasi per jumlah unit pekerjaan (cumulative average) yang dilakukan berulang pada urutan pengulangan yang ke dua kalinya akan menghasilkan output sebesar persentase dari learning rate pekerjaan tersebut (Thomas et al., 1986). Adapun 70\% learning rate berarti bahwa cumulative average pada urutan pengulangan yang ke dua kalinya berkurang sebanyak 30\% (Oglesby et al., 1989). Adapun grafik learning rate 50\%, 70\%, 90\% dapat dilihat pada gambar 1.

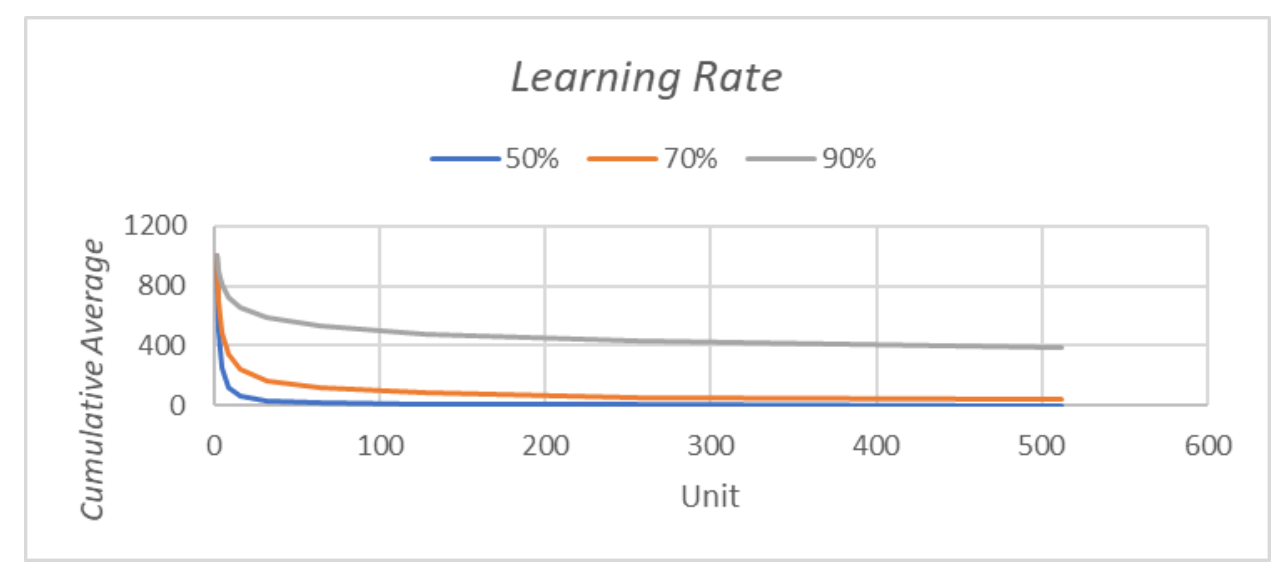

Gambar 1. Grafik Learning Rate

\section{Kurva Belajar Log-Linear}

Kurva belajar log-linear (gambar 2) mengkorelaksikan hubungan antara rata-rata durasi per jumlah unit dengan jumlah unit yang dihasilkan (Zhang et al., 2014). Model ini dijabarkan oleh rumus 1.

$$
\mathrm{T}_{\mathrm{x}}=\mathrm{C}_{1} \cdot \mathrm{X}^{-\mathrm{n}}
$$

Keterangan:

$\mathrm{T}_{\mathrm{x}} \quad=$ Rata-rata durasi untuk menghasilkan $\mathrm{X}$ unit.

$\mathrm{C}_{1} \quad=$ Waktu yang diperlukan untuk menyelesaikan unit pertama.

$\mathrm{n}=$ Kelandaian dari kurva belajar pada skala logaritma.

Nilai $\mathrm{n}$ berkisar antara 0 dan $1(0 \leq \mathrm{n} \leq 1)$. Nilai $\mathrm{n}$ yang mendekati 1 mengindikasikan bahwa pekerja memiliki learning rate yang rendah dan sebaliknya (Anzanello dan Fogliatto, 2011). Nilai n tersebut dapat dihitung menggunakan rumus 2 .

$$
\mathrm{n}=-\frac{\log \varphi}{\log 2}
$$

Keterangan:

$\varphi \quad=$ Learning rate

\section{Durasi Spesifik Unit $\mathbf{T}_{(\mathrm{x})}$}

Durasi penyelesaian pekerjaan pada unit ke-x dapat diprediksi dengan kurva belajar log-linear pada gambar 2 dengan menghitung durasi spesifik unit $\mathrm{T}_{(\mathrm{x})}$. Untuk mendapatkan durasi spesifik unit $\left(\mathrm{T}_{(\mathrm{x})}\right)$ maka durasi untuk menghasilkan $\mathrm{X}$ unit $\left(\mathrm{X} . \mathrm{T}_{\mathrm{x}}\right)$ dikurangi dengan durasi untuk menghasilkan $\mathrm{X}-1$ unit $(\mathrm{X}-1)$. $\left.\mathrm{T}_{\mathrm{x}-1}\right)$ seperti pada rumus 3 .

$$
\mathrm{T}_{(\mathrm{x})}=\left[\mathrm{X} \cdot \mathrm{T}_{\mathrm{x}}\right]-\left[(\mathrm{X}-1) \cdot \mathrm{T}_{\mathrm{x}-1}\right]
$$




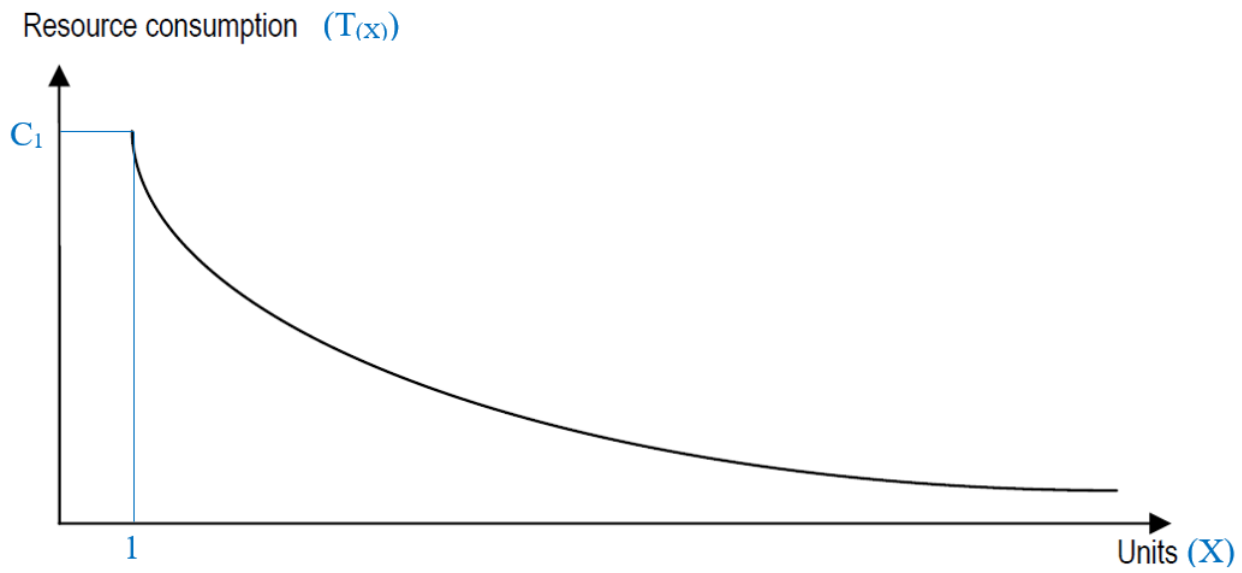

Gambar 2. Kurva Belajar Log-Linear (Gottlieb dan Haugbolle, 2010)

\section{METODOLOGI PENELITIAN}

Data Proyek yang dikumpulkan yakni laporan harian pekerjaan dinding (pemasangan batu bata, plesteran, acian, cat dasar dan cat finish) selama satu bulan untuk mendapatkan hasil volume pekerjaan dinding, waktu kerja dan jumlah pekerja. Langkah selanjutnya yakni menghitung learning rate $(\varphi)$ pekerjaan pasangan dinding bata, plesteran, acian, cat dasar dan cat finish. Kemudian dilanjutkan dengan memprediksi durasi pekerjaan pasangan dinding bata, plesteran, acian, cat dasar dan cat finish dengan kurva belajar log-linear dan menghitung akurasi dari prediksi durasi pekerjaan tersebut. Akurasi perhitungan tersebut dihitung dengan membandingkan durasi pekerjaan setiap $20 \mathrm{~m}^{2} /$ orang dengan durasi spesifik unit $\mathrm{T}_{(\mathrm{x})}$. Di sisi lain setelah menghitung learning rate juga dapat dilakukan pengurangan jumlah tenaga kerja dan dilakukan upaya penghematan biaya pekerja menggunakan konsep kurva belajar log-linear. Hasil perhitungan berikutnya akan disajikan dan dibahas serta dibuat suatu kesimpulan. Adapun tahapan penelitian secara skematis dalam bentuk began alir dapat dilihat pada gambar 3 .

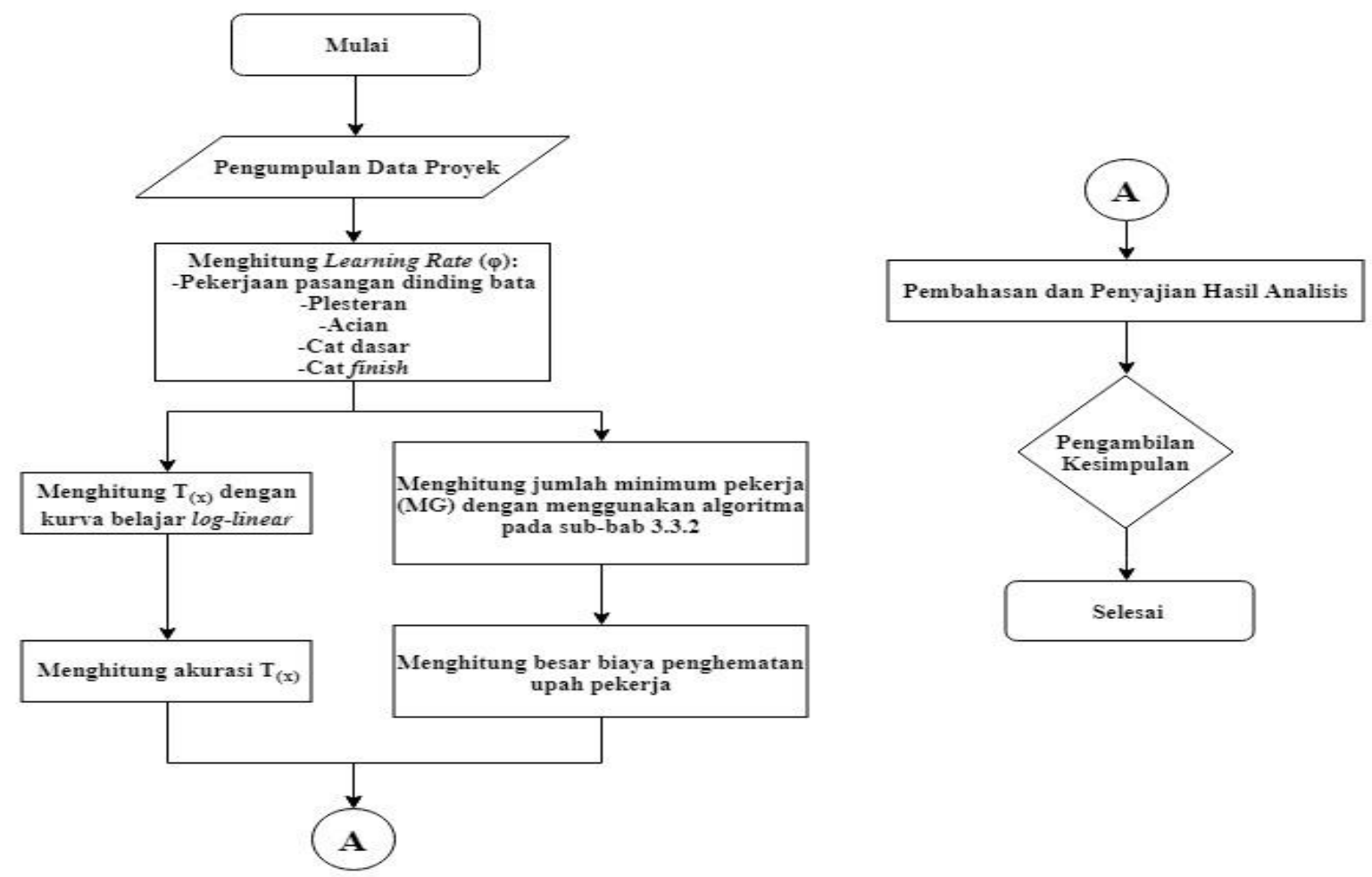

Gambar 3. Bagan Alir Tahapan Penelitian 


\section{Menghitung Durasi Spesifik Unit $\mathbf{T}_{(\mathrm{x})}$}

Data volume pekerjaan pasangan batu bata, plester, acian, cat dasar dan cat finish yang didapat dari proyek akan diolah terlebih dahulu menjadi durasi pekerjaan setiap $20 \mathrm{~m}^{2} /$ orang. Adapun penelitian ini menetapkan satu unit perulangan pekerjaan berulang sebesar $20 \mathrm{~m}^{2}$ / orang dikarenakan proyek perumahan di daerah Jabodetabek biasanya menghasilkan hasil pasangan batu bata berkisar 15 s.d. $25 \mathrm{~m}^{2}$ per harinya. Kemudian dihitung nilai rata-rata durasi per jumlah unit (Cumulative Average) dari durasi tersebut.

Nilai cumulative average ini dipakai untuk mendapatkan learning rate $(\varphi)$ dari pekerjaan dinding. Learning rate $(\varphi)$ pekerjaan tersebut akan dipakai untuk memprediksi rata-rata durasi per jumlah unit $\left(\mathrm{T}_{\mathrm{x}}\right)$ dengan menggunakan rumus 2.1 dan rumus 2.2. Berikutnya dihitung durasi spesifik unit $\left(\mathrm{T}_{(\mathrm{x})}\right)$ dengan menggunakan rumus 2.3.

\section{Penghematan Biaya Pekerja dengan Kurva Belajar Log-Linear}

Total biaya pekerja (ATR) yang diperlukan untuk menyelesaikan semua unit dalam suatu pekerjaan dapat dihitung dengan mengalikan jumlah waktu pekerjaan (AT) dan harga satuan pekerja (WR), seperti yang diperlihatkan pada rumus 4 .

$$
\mathrm{ATR}=\mathrm{AT} \cdot \mathrm{WR}
$$

Keterangan:

ATR = Total biaya pekerja

AT = Jumlah waktu pekerjaan.

WR = Harga satuan pekerja.

Dikarenakan harga satuan pekerja (WR) selalu konstan, maka untuk meminimalkan jumlah biaya dapat dilakukan dengan meminimalkan jumlah waktu pekerjaaan (AT) menjadi jumlah waktu pekerjaan minimum (MT). Nilai jumlah waktu pekerjaaan (AT) dapat dihitung menggunakan rumus 5 sedangkan nilai jumlah waktu pekerjaan minimum (MT) dapat dihitung dengan menggunakan rumus 6.

$$
\begin{aligned}
\mathrm{AT} & =\mathrm{AG} \cdot \mathrm{TD} \\
\mathrm{MT} & =\mathrm{MG} \cdot \mathrm{TD}
\end{aligned}
$$

Keterangan:

$$
\begin{array}{ll}
\mathrm{AG} & =\text { Jumlah pekerja } \\
\mathrm{MG} & =\text { Jumlah pekerja minimum. } \\
\mathrm{TD} & =\text { Batas durasi pekerjaan. }
\end{array}
$$

Berikutnya jumlah waktu pekerjaan minimum (MT) dapat dipakai untuk menghitung total biaya pekerja minimum (MTR) seperti pada rumus 7 .

$$
\mathrm{MTR}=\mathrm{MT} . \mathrm{WR}
$$

Sedangkan nilai jumlah minimum kelompok pekerja (MG) dihitung dengan algoritma pada program Ruby. Langkah dari algoritma tersebut ditampilkan sebagai berikut:

\section{BEGIN}

Menghitung TG dengan rumus (3.5);

Dimulai dengan mengatur nilai $\mathrm{MG}=1, \mathrm{RU}=\mathrm{U}$;

$F O R \mathrm{i}=1$ to $\mathrm{TG} D O$

Mencari integer terbesar dari $\mathrm{K}_{\mathrm{i}}{ }^{*}$ yang membuat pertidaksamaan:

IF $\mathrm{RU} \geq \mathrm{K}_{\mathrm{i}} *$ THEN

$$
\mathrm{T}_{1-\mathrm{Ki}^{*}} \leq\left(\mathrm{TD}-\mathrm{C}_{1} \frac{\mathrm{i}-1}{\mathrm{TG}}\right) \text { benar; }
$$

$\mathrm{K}_{\mathrm{i}}=\mathrm{K}_{\mathrm{i}}^{*}, \mathrm{RU}=\mathrm{RU}-\mathrm{K}_{\mathrm{i}}^{*}, \mathrm{MG}=\mathrm{MG}+1$;

ELSE

$\mathrm{K}_{\mathrm{i}}=\mathrm{RU}$, dan sisa kelompok tidak dipekerjakan, return;

ENDIF

\section{ENDFOR}

END

Keterangan:

$\mathrm{K}_{\mathrm{i}} \quad$ = Jumlah unit yang dikerjakan oleh kelompok (i)

$\mathrm{K}_{\mathrm{i}}^{*} \quad$ = Jumlah maksimum unit yang boleh dikerjakan oleh kelompok (i) 


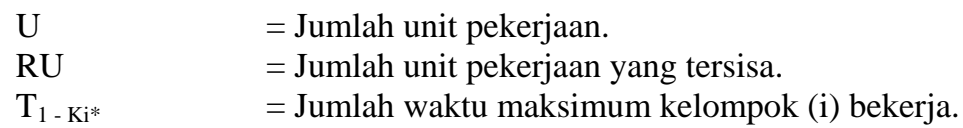

Sebelum menghitung jumlah minimum pekerja (MG) perlu dihitung jumlah pekerja teoritis (TG) terlebih dahulu untuk membatasi iterasi yang akan dilakukan oleh algoritma. Nilai jumlah pekerja teoritis (TG) dihitung menggunakan rumus 8 yang berdasarkan perhitungan perencanaan jumlah pekerja minimum line of balance (LOB) dengan waktu pengerjaan setiap unit yang konstan dan batas durasi pekerjaan yang tidak berubah.

$$
\mathrm{TG}=\left|\frac{\mathrm{U}-1}{\mathrm{~T}_{\mathrm{n}}-\mathrm{C}_{\mathrm{1}}} \cdot \mathrm{C}_{1}\right|
$$

Sedangkan jumlah waktu maksimum kelompok (i) bekerja $\left(\mathrm{T}_{1-\mathrm{Ki}^{*}}\right)$ dapat dihitung dengan cara mengalikan jumlah maksimum unit yang dikerjakan oleh kelompok (i) $\left(\mathrm{K}_{\mathrm{i}}^{*}\right)$ dan rata-rata durasi untuk menyelesaikan $\mathrm{K}_{\mathrm{i}}{ }^{*}$ unit $\left(\mathrm{T}_{\mathrm{Ki}} *\right)$ seperti yang dapat dilihat pada rumus 9 .

$$
\mathrm{T}_{1-\mathrm{Ki}^{*}}=\mathrm{K}_{\mathrm{i}}^{*} \cdot \mathrm{T}_{\mathrm{Ki}^{*}}
$$

Adapun constraints 10 s.d. 12 ditetapkan untuk mengecek kebenaran perhitungan.

$$
\begin{gathered}
\mathrm{U}=\sum_{\mathrm{i}=1}^{\mathrm{MG}} \mathrm{K}_{\mathrm{i}} \\
0 \leq \mathrm{K}_{\mathrm{i}} \leq \mathrm{K}_{\mathrm{i}}^{*} \\
\mathrm{~K}_{\mathrm{i}} \leq \mathrm{K}_{\mathrm{i}-1} *
\end{gathered}
$$

\section{HASIL DAN PEMBAHASAN}

Jumlah proyek yang diamati pada penelitian ini sebanyak dua proyek yakni proyek HH dan proyek WH. Proyek HH merupakan proyek yang membayar pekerjanya secara borongan mingguan yakni dengan membayar pekerjanya sesuai dengan hasil pekerjaan tersebut setiap minggunya, sedangkan proyek WH merupakan proyek yang membayar pekerjanya secara harian yakni dengan membayar upah pekerja sebesar standar daerah yang sama setiap harinya.

\section{Learning Rate ( $\varphi)$}

Hasil perhitungan learning rate dari proyek HH dan WH secara ringkas disajikan pada gambar 4.

\section{Learning Rate Proyek HH dan WH}

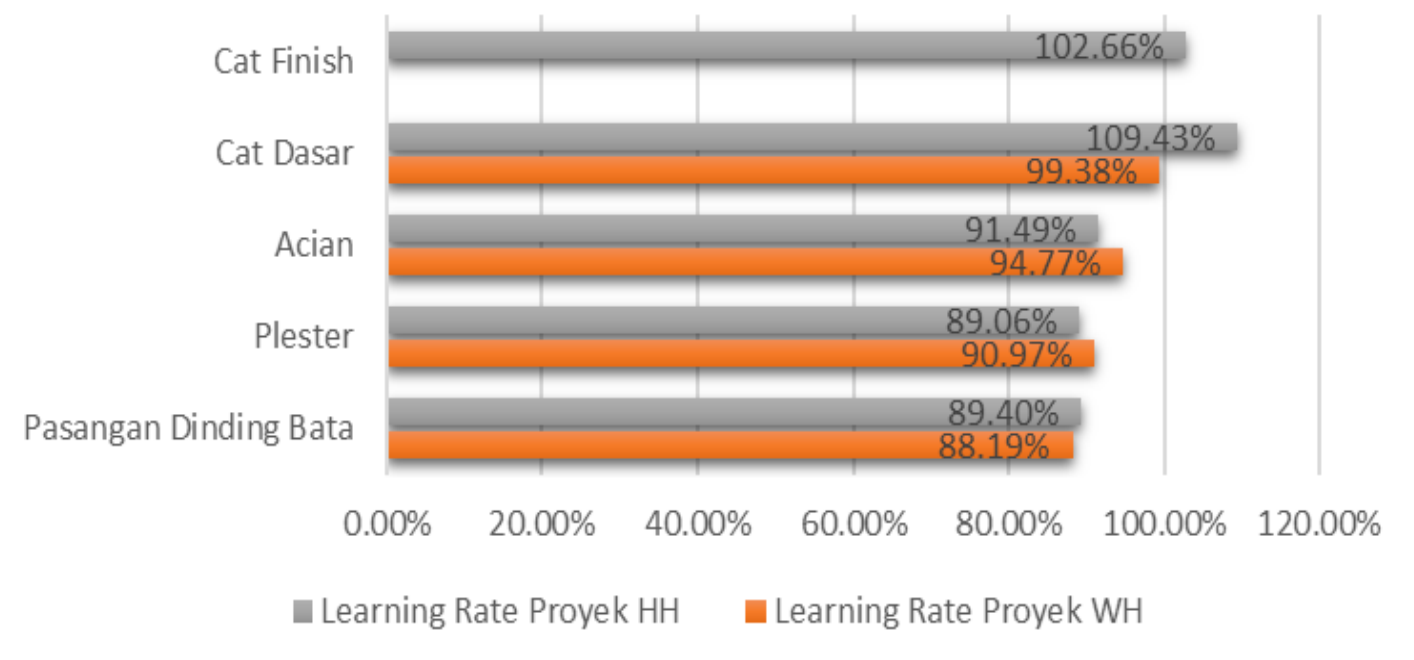

Gambar 4. Learning Rate Proyek HH dan WH 
Learning rate cat dasar dan cat finish (learning rate > 99,38 \%) cenderung lebih tinggi dibandingkan pekerjaan pasangan dinding bata, plester maupun acian (learning rate 88,19\% s.d. 94.77\%). Hal ini berarti bahwa peningkatan produktivitas pada pekerjaan pasangan dinding bata, plester dan acian lebih besar dibandingkan dengan pekerjaan cat dasar dan cat finish. Fenomena ini terjadi dikarenakan pekerjaan pasangan dinding bata, plester dan acian merupakan pekerjaan yang memiliki tingkat kesulitan lebih rendah dibandingkan dengan pekerjaan cat dasar dan cat finish sehingga kecepatan proses belajar pekerja lebih tinggi pada pekerjaan pasangan dinding bata, plester dan acian. Kecepatan proses belajar yang lebih tinggi ini menyebabkan waktu yang dibutuhkan untuk menyelesaikan pekerjaan lebih sedikit sehingga jumlah pekerja dapat dikurangi tanpa mempengaruhi hasil pekerjaan.

Hasil perhitungan learning rate pekerjaan plester dan acian pada proyek $\mathrm{HH}$ yang membayar pekerjanya secara borongan lebih kecil dibandingkan dengan proyek WH yang membayar pekerjanya secara harian sedangkan learning rate pada pekerjaan pasangan dinding bata dan cat dasar pada proyek HH lebih besar dibandingkan dengan proyek WH. Hasil learning rate pada pekerjaan plester dan acian proyek HH dan WH ini sesuai secara teoritis dikarenakan pada proyek yang membayar pekerjanya secara borongan akan memberikan motivasi lebih kepada pekerjanya. Namun kesesuaian tersebut tidak tampak pada pekerjaan pasangan dinding bata dan cat dasar proyek HH dan WH. Fenomena ini dapat terjadi dikarenakan oleh gangguan pada pekerjaan proyek HH dan WH. Gangguan tersebut berupa kejadian seperti pada hari tertentu seorang tukang dapat diminta membantu pekerjaan plafon, membuat kolom praktis, membuat balok praktis maupun memasang perancah sebelum menyelesaikan pekerjaan dinding tersebut dan kembali membantu mengerjakan pekerjaan dinding pada hari berikutnya. Kejadian lain dapat berupa pekerja yang diganti dengan orang lain sebelum pekerjaan selesai.

\section{Durasi Spesifik Unit $\mathbf{T}_{(\mathbf{x})}$}

Akurasi dari durasi spesifik unit $\mathrm{T}_{(\mathrm{x})}$ proyek $\mathrm{HH}$ dan $\mathrm{WH}$ secara ringkas disajikan pada gambar 5.

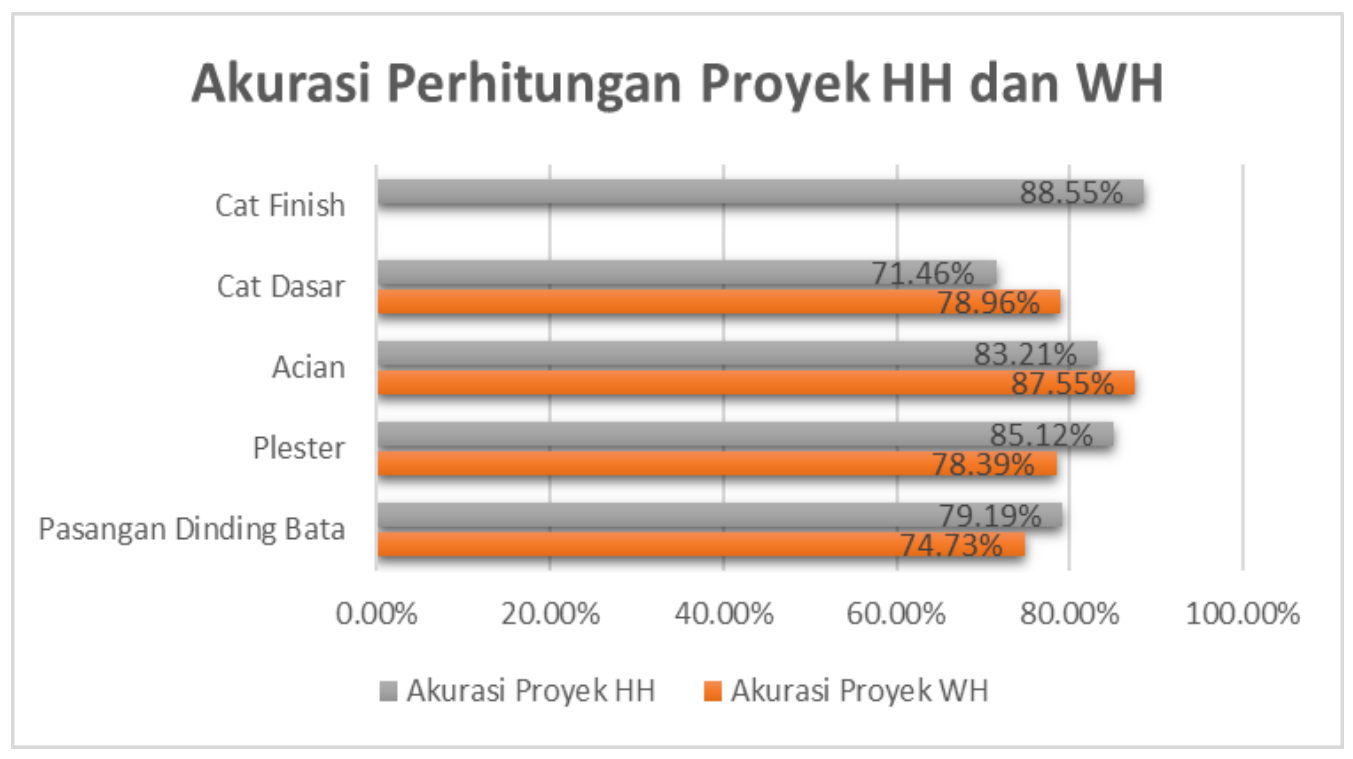

Gambar 5. Akurasi Durasi Spesifik Unit Proyek HH dan WH

Akurasi dari durasi spesifik unit $\mathrm{T}_{(\mathrm{x})}$ proyek $\mathrm{HH}$ berkisar $71,46 \%$ s.d. $88,55 \%$ dengan rata-rata sebesar $81,51 \%$. Sedangkan pada proyek WH berkisar $74,73 \%$ s.d. $87,55 \%$ dengan rata-rata sebesar $79,91 \%$. Kemudian rata-rata akurasi durasi spesifik unit untuk kedua proyek sebesar $80,71 \%$.

Perbandingan data aktual atau durasi pekerjaan setiap $20 \mathrm{~m}^{2} /$ orang terhadap durasi spesifik unit diberikan contoh pada pekerjaaan pasanngan dinding bata pada gambar 6. Hasil perhitungan menemukan bahwa nilai data aktual untuk setiap pekerjaan memiliki nilai yang fluktuatif. Hasil fluktuatif ini disebabkan oleh keadaan proyek yang tidak selalu sama setiap harinya sehingga situasi harian yang serupa jarang ditemukan. Jika dibandingkan antara proyek HH dan proyek WH maka terlihat dengan jelas bahwa hasil fluktuatif ini lebih terlihat lebih stabil pada proyek HH dibandingkan dengan proyek WH. Perbedaan ini disebabkan oleh motivasi pekerja yang lebih tinggi untuk mempertahankan kecepatan bekerjanya jika dibayar secara borongan dibandingkan dengan dibayar secara harian. Adapun proyek HH membayar pekerjanya secara borongan sedangkan pada proyek WH pembayaran pekerja dilakukan secara harian. 

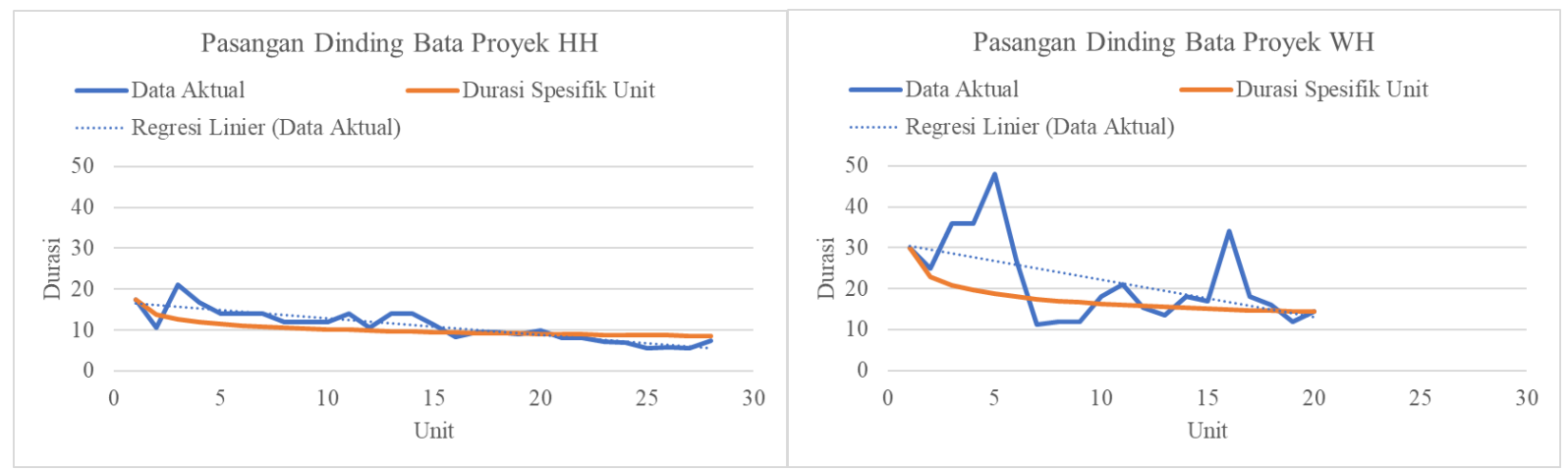

Gambar 6. Grafik Durasi Spesifik Unit $\mathrm{T}_{(\mathrm{x})}$ Pasangan Dinding Bata Proyek HH dan WH

\section{Penghematan Biaya Pekerja}

Perhitungan penghematan biaya pekerja ditetapkan dengan ketentuan sebagai berikut: Batas durasi pekerjaan (TD) dibuat kedalam tiga cases, yakni: (Case 1 : TD = 6 Hari), (Case $2:$ TD = 9 Hari), (Case $3:$ TD = 12 Hari); Perhitungan algoritma tidak dilakukan untuk pekerjaan yang mempunyai learning rate di atas $100 \%$ sehingga nilai MG sama dengan TG; Nilai AG dibuat sama dengan nilai TG; Penghematan biaya pekerja dihitung dari selisih ATR dan MTR; Total penghematan biaya pekerja merupakan perjumlahan penghematan biaya pekerja setiap pekerjaan; $\%$ Penghematan biaya pekerja dihitung dengan membagi total penghematan biaya pekerja dengan perjumlahan ATR setiap pekerjaan; Harga satuan pekerja (WR) memakai biaya pekerja tukang batu di daerah Jabodetabek pada umumnya, sebesar Rp 130.000,00 / hari.

Hasil perhitungan penghematan dan \% penghematan biaya pekerja ditampilkan dalam bentuk grafik pada gambar 7 .

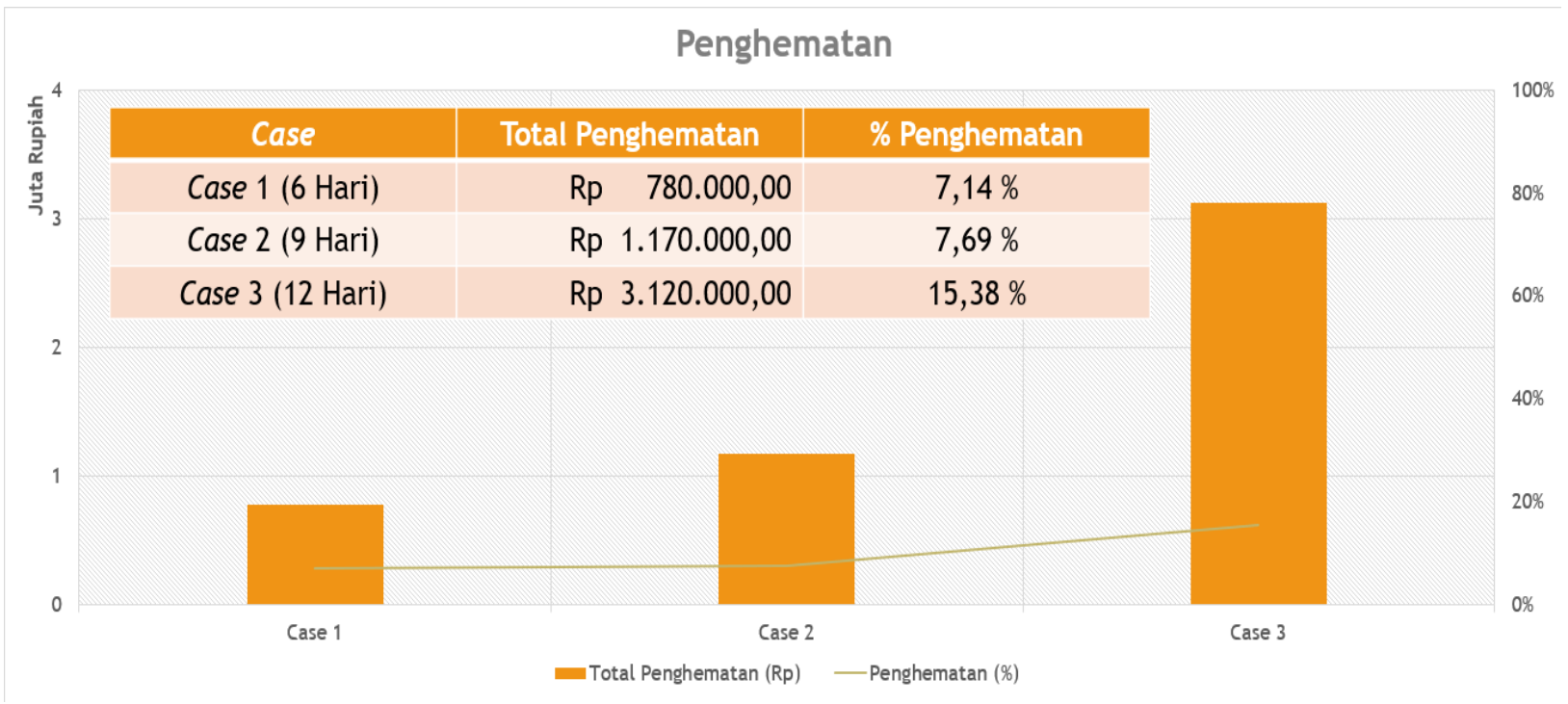

Gambar 7. Grafik Penghematan Biaya Pekerja

Gambar 7 menunjukkan besar penghematan biaya pekerja dan persentase penghematan biaya pekerja meningkat setiap bertambahnya durasi pekerjaan. Durasi pekerjaan ini berkaitan dengan jumlah repetisi pekerjaan yang dilakukan. Hal ini menunjukkan bahwa penghematan dan \% penghematan biaya pekerja dari efek belajar oleh kurva belajar log-linear akan semakin besar seiring bertambahnya jumlah repetisi pekerjaan. Peningkatan penghematan dan \% penghematan seiring bertambahnya jumlah repetisi ini disebabkan oleh kecepatan belajar pekerja yang meningkat seiring dengan peningkatan jumlah repetisi tersebut. 


\section{KESIMPULAN}

Kesimpulan penelitian ini adalah sebagai berikut:

1. Tingkat kesulitan dan jumlah repetisi pekerja merupakan faktor yang berpengaruh terhadap kecepatan belajar pekerja. Semakin tinggi kecepatan belajar pekerja maka peningkatan produktivitas pekerja akan semakin tinggi. Peningkatan produktivitas ini dapat dimanfaatkan untuk melakukan penghematan terhadap biaya pekerja.

2. Tingkat kesulitan mempengaruhi kecepatan belajar pekerja.

a. Semakin rendah tingkat kesulitan maka kecepatan belajar pekerja akan semakin tinggi.

b. Tingkat kesulitan untuk pekerjaan pasangan dinding bata, plester dan acian lebih rendah dibandingkan dengan pekerjaan cat dasar dan cat finish.

c. Hasil analisis menghasilkan learning rate pekerjaan dinding bata, plester dan acian sebesar 88,19\% s.d. $94,77 \%$. Learning rate pekerjaan cat dasar dan cat finish diatas 99,38\%.

3. Jumlah repetisi pekerjaan mempengaruhi kecepatan belajar pekerja.

a. Semakin banyak jumlah repetisi pekerjaan maka kecepatan belajar pekerja akan semakin tinggi.

b. Kecepatan belajar pekerja ini akan berpengaruh terhadap penghematan biaya pekerja oleh kurva belajar log-linear.

c. Hasil analisis dengan jumlah repetisi pada hari ke 6 s.d. 12 menghasilkan $\%$ penghematan biaya pekerja yang meningkat dari 7,14 s.d. $15,38 \%$.

4. Kesimpulan 1 s.d. 3 secara sederhana disajikan dengan bagan pada gambar 8 berikut.

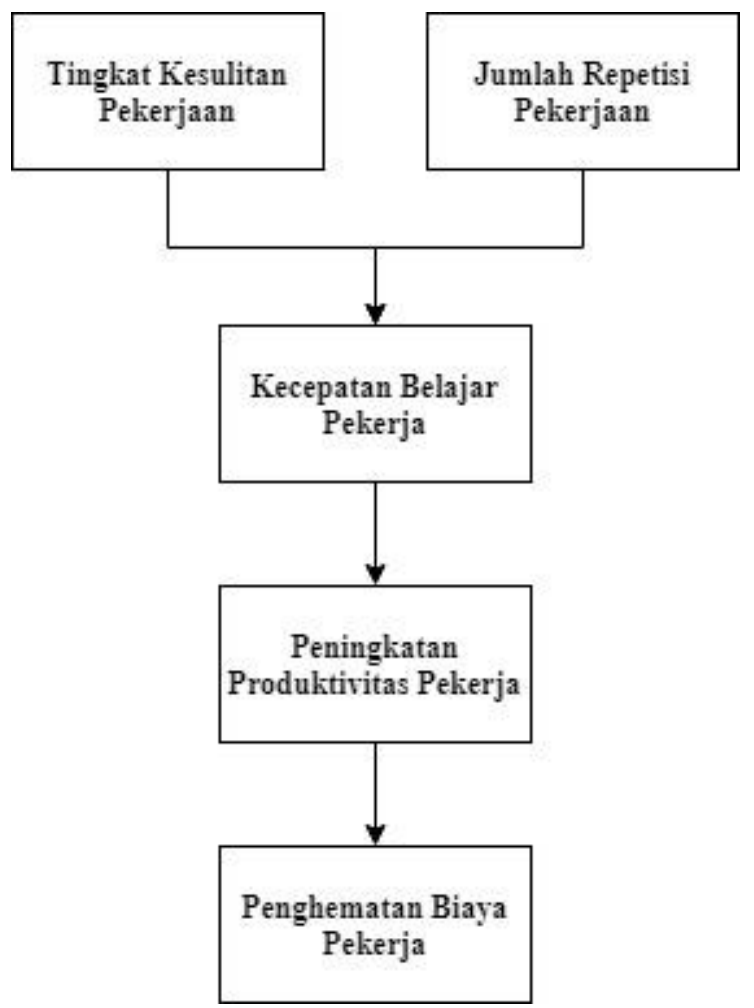

Gambar 8 Bagan Kesimpulan 1 s.d. 3

5. Tingkat akurasi prediksi durasi pekerjaan oleh kurva belajar log-linear sebesar $80,71 \%$.

6. Sistem pembayaran pekerja mempengaruhi motivasi pekerja.

a. Pekerja yang dibayar secara borongan memiliki motivasi yang lebih tinggi dibandingkan dengan pekerja yang dibayar secara harian.

b. Grafik durasi spesifik unit $\mathrm{T}_{(\mathrm{x})}$ menunjukkan bahwa pekerja yang dibayar secara borongan dapat mempertahankan kecepatan bekerjanya lebih baik dibandingkan dengan pekerja yang dibayar secara harian. 


\section{SARAN}

Saran untuk penelitian ini adalah sebagai berikut:

Kurva belajar log-linear telah banyak dilakukan pengembangannya, seperti kurva belajar Stanford B, Dejong's, Plateau, S-Curve, Knecht, Quadratic, Cubic, Exponential 2-Parameter, Exponential 3-Parameter, Hyperbolic 2Parameter, Hyperbolic 3-Parameter dan lain-lain (Srour et al., 2015). Namun penelitian ini berfokus pada kurva belajar log-linear. Untuk selanjutnya penelitian ini dapat dilanjutkan dengan menggunakan variasi lain dari kurva belajar yang sudah ada.

\section{DAFTAR PUSTAKA}

Anzanello, M. J. dan Fogliatto, F. S. (2011). "Learning Curve Models and Applications: Literature Review and Research Directions.” International Journal of Industrial Ergonomics, Vol. 41, Issue. 5

Ervianto, W. I. (2007). Teori Aplikasi Manajemen Proyek Konstruksi. Andi Publisher, Yogyakarta. Indonesia.

Gottlieb, S. C. dan Haugbolle, K. (2010). The Repetition Effect in Building and Construction Works: A literature review. Statens Byggeforskningsinstitut, Danish Building Research Institute. Denmark.

Lee, B., Lee, H. S., Park, M. dan Kim, H. (2015). "Influence Factors of Learning-Curve Effect in High-Rise Building Constructions." ASCE Journal of Construction Engineering and Management, Vol. 141, Issue. 8

Oglesby, C. H., Parker, H.W. dan Howell, G.A. (1989). Productivity Improvement In Construction. McGraw-Hill, New York. United States of America.

Rosenbaum, S., Toledo, M. dan Gonzalez, V. (2012). "Green-Lean Approach for Assessing Enviromental and Production Waste in Construction." Proceedings for the $20^{\text {th }}$ Annual Conference of the International Group for Lean Construction, San Diego

Srour, F. J., Kiomjian, D. dan Srour, I. M. (2016). "Learning Curves in Construction: A Critical Review and New Model." ASCE Journal of Construction Engineering and Management, Vol. 142, Issue. 4

Thomas, H. R., Mathews, C. T. dan Ward, J. G. (1986). "Learning Curve Models of Construction Productivity." ASCE Journal of Construction Engineering and Management, Vol. 112, Issue. 2

Zhang, L., Zou, X. dan Kan, Z. (2014). "Improved Strategy for Resource Allocation in Repetitive Projects Considering the Learning Effect." ASCE Journal of Construction Engineering and Management, Vol. 140, Issue. 11 